\title{
Investigation of herbaceous species adapted to snowfence areas
}

\author{
BARRY L. PERRYMAN, W.A. LAYCOCK, AND DAVID W. KOCH
}

Authors are assistant professor, professor emeritus, Department of Renewable Resources, and professor, Department of Plant Science, University of Wyoming, Laramie, Wyo. 82071.

Abstract

Decreases in biomass and cover, as well as changes in species composition have occurred on rangelands affected by snowdrifts behind 3.8 meter tall "Wyoming" type snowfences along Interstate 80 in southeast Wyoming. Within the state of Wyoming, government agencies are responsible for the mitigation of any adverse effects associated with snowfences. These agencies need information which may aid mitigation efforts. In this study, 13 grass species and 2 tillage treatments (till and notill) were evaluated in the field on both drift and non-drift areas, to determine the potential of each for the revegetation of snowfence sites. Evaluation was based on foliar cover at the end of the first growing season and aboveground biomass production after the second growing season. The project included plantings on 2 different soil depth sites $(<50 \mathrm{~cm}$ and $>50 \mathrm{~cm})$ that were treated as 2 separate experiments. Results indicate that pubescent wheatgrass 'Luna' (Elytrigia intermedia[Host]Nevski), thickspike wheatgrass 'Critana' (Elymus lanceolatus [Scribn. \& J.G. Smith] Gould), and 2 varieties of slender wheatgrass 'Pryor' and 'San Luis'(Elymus trachycaulus [Link] Gould ex Shinners), were superior in cover and aboveground biomass production when planted in combination with tilled plots. Tufted hairgrass (Deschampsia caespitosa [L.] Beauv.) exhibited the least potential for cover and aboveground biomass production.

Key Words: species performance, reclamation

The construction of Interstate Highway 80 across Wyoming during the early 1970s brought attention to the impact of blowing snow on travelers and the transportation system. A snowfence system was designed and installed to mitigate these impacts (Tabler 1973). The economic benefits that accrued from the snowfence system included a $70 \%$ decease in accidents due to ground blizzards, a $27 \%$ decrease in wind only caused accidents, and a $33 \%$ reduction of snow removal costs. Snowfences in this system are designed for a lifespan of 25 years and construction costs can be amortized over a 10 year period (Talder and Furnish 1982).

Between 1971 and 1979, approximately 53 kilometers of snowfence were constructed between Laramie and Walcott, Wyoming (Tabler and Furnish 1982). Most of these fences are of the $3.8 \mathrm{~m}$ high "Wyoming" type described by Tabler (1974).

Research was funded by the Wyoming Department of Transportation and the Departments of Rangeland Ecology and Watershed Management, and Plant, Soil, and Insect Sciences, University of Wyoming.

Manuscript accepted 16 July 1999.
Resumen

Las disminuciones de la biomasa y la tapa, tanto como los cambios de la composición de las especies, han ocurrido en las praderas afectadas por la nieve acumulada detrás de las cercas del tipo "Wyoming" de 3.8 metros de altura a lo largo de la autopista 80 en el sudoeste de Wyoming. Dentro del estado de Wyoming, agencias del gobierno están responsables para la mitigación de cualquier efecto adverso asociado con las cercas de nieve. Estas agencias necesitan información que tal vez apoyará los esfuerzos de la mitigación. En este estudio, trece especies del pasto y dos tratamientos de labranza (cultivo y no cultivo) fueron evaluados en el campo en dos áreas, la con ventisquero y la sin ventisquero, para determinar el potencial de cada una para la revegezación alrededor de las cercas de nieve. La evaluación fue basada en la tapa del follaje al fin de la primera temporada del crecimiento y la producción de la biomasa sobre la tierra después de la segunda temporada del crecimiento. El proyecto incluyó el plantar en dos sitios diferentes de espesos diferentes $(<50 \mathrm{~cm}$ y $>50 \mathrm{~cm})$ que fueron tratados como dos experimentos diferentes. Los resultados indican que el pasto de trigo pubescente 'Luna' (Elytrigia intermedia [Host] Nevski), el pasto de trigo espinagruesa 'Critana' (Elymus lanceolatus [Scribn. \& J.G. Smith] Gould), y dos variedades del pasto de trigo delgado 'Pryor' y 'San Luis' (Elymus trachycaulus [Link] Gould ex Shinners), eran superior en la tapa y la producción de la biomasa sobre la tierra cuando fueron plantados en combinación de los lotes cultivados. El pasto de pelo copeludo (Deschampsia caespi tosa [L.] Beauv.) exhibió el potencial menor para la tapa y la producción de la biomasa sobre la tierra.

The snowfence system along Interstate Highway 80 is designed to trap as much snow as possible. This results in very large fenceinduced snowdrifts. At maximum capacity, snow depth at the deepest part of the drift is approximately $4.3 \mathrm{~m}$. Drifts begin to form late in the fall and persist into late spring or early summer, sharply reducing the length of the growing season on these sites. Weaver and Collins (1977) found that community composition as well as cover and productivity could change as a result of shortened growing seasons on late melting natural snowdrift areas. They also discovered higher mean growing season temperatures resulting from the absence of a cool spring on the same sites. Pope (1985) demonstrated that lower cation exchange capacities, lower pHs, and decreased phosphorous availability all occur on snowfence sites when compared to adjacent non-drifted sites in southeast Wyoming. It is logical to assume that plants will respond to these altered climatic and soil characteristics. 
In July of 1989, the Albany County Weed and Pest District conducted a survey of the vegetation occurring on snowfence sites located along Interstate Highway 80 in Albany county, Wyo. (Pomeroy 1990). The results of the survey indicated that 3.8 $m$ high snowfence systems had negatively impacted the native rangeland vegetation by altering species composition, and decreasing cover and aboveground biomass production. The primary reason for these shifts was a reduction in the native cool season grass component and an increase in annual and perennial forbs. Guernsey (1996) also documented similar shifts in species composition and standing crop at snowfence sites along Halleck Ridge in southcentral Wyoming. The objectives of this project were to determine which cultural practices and herbaceous species might be best suited for revegetating the microclimate of snowdrift areas behind $3.8 \mathrm{~m}$ high snowfences.

\section{Methods and Materials}

\section{Study Area}

The study area was located in Albany county, Wyo., along a $70 \mathrm{~km}$ section of Interstate Highway 80 between Laramie and Arlington, Wyo., at an elevation of approximately $2,165 \mathrm{~m}$. Climate is typical of the Laramie Basin (Martner 1986). Mean annual air temperature is $4.4 \mathrm{C}^{\circ}$ with a mean daily maximum of $12.5 \mathrm{C}^{\circ}$ and a mean daily minimum of $-2.9 \mathrm{C}^{\circ}$. Mean annual precipitation is $300-350 \mathrm{~mm}$ with $45 \%$ occurring during the growing season. Mean annual snowfall is 150-200 $\mathrm{cm}$. The snow drifting season typically begins around 1 November and ends around 1 April of the subsequent calendar year. Prevailing winds during the snow season are downslope from the west. The average potential growing season (based on temperature) is 113 days, and the actual snow free period for the drift area during the first year of the project was 165 days, 160 days during the second year.

\section{Snow Drift Characteristics}

Snow drift depth was measured for all fences at the time of maximum drift accumulation along permanent transects located in the middle of each plot. Measurements were taken in each year of the study. A probe was used to take depth measurements at specified intervals along each transect. These measurements were utilized to calculate drift density described by Tabler (1985).
Pre-melt density:

$$
\begin{aligned}
& \mathrm{p}=522-(304 / 1.485 \mathrm{z})\left(1-\mathrm{e}^{[-1.485 \mathrm{z}]}\right) \\
& \text { where } \mathrm{p}=\operatorname{density}\left(\mathrm{kg} / \mathrm{m}^{3}\right) \\
& \mathrm{z}=\operatorname{depth}(\mathrm{m})
\end{aligned}
$$

Drift density was converted to a water equivalent (WE) by the equation:

$\mathrm{p}=\mathrm{WE} /$ drift crossectional area where WE = water equivalent $\left(\mathrm{m}^{3} / \mathrm{m}\right.$ of fence length)

The actual precipitation equivalent was calculated by dividing total water equivalent value by the ground surface area covered by the drift.

Combining the drift water equivalent with the actual precipitation occurring outside the drift season provided an average annual precipitation equivalent for drift areas. During the study period, the drift areas received a mean annual precipitation equivalent of $850 \mathrm{~mm}$, approximately 3 times the mean annual precipitation for the adjacent non-drift area. Melt rates rarely exceed infiltration rates, allowing almost $100 \%$ of the melt water to infiltrate the soil profile (Tabler 1985). Maximum drift depths were approximately $3 \mathrm{~m}$ both winters, and the drift area extended from approximately $9 \mathrm{~m}$ to $30 \mathrm{~m}$ from the fences. The fences utilized in the study were all constructed in 1973.

The major land use of the area is livestock grazing (both sheep and cattle), and the area also serves as habitat for major wildlife species (antelope, deer, and elk).

\section{Project Design}

Two independent studies were conducted on sites with different soil depths, a shallow ( $<50 \mathrm{~cm}$ soil depth) and a deep site (50-100 cm soil depth) representative of the area. Both studies were arranged into a randomized complete block $2 \times 2 \times$ 13 factorial design, including 3 replicate blocks $(55 \mathrm{~m}$ x $91 \mathrm{~m})$ each on the leeward side of a snowfence, 2 tillage treatments (till and no-till), 2 snow drift treatments (drift and non-drift), and 13 herbaceous species treatments (Fig. 1). Drift treatments were designated as drift area (9$30 \mathrm{~m}$ from fence) and non-drift area (30 m to end of plots, $91 \mathrm{~m}$ ).

Shallow soil sites were upland sites typical of the area (Typic Argiborolls) with roots penetrating to $35 \mathrm{~cm}$. Deep soil sites were lowland sites typical of the area (Typic Aeric Calciaquolls) with roots penetrating to $80 \mathrm{~cm}$. The no-till alternative was included because much of the soil adjacent to snowfences was extremely rocky and difficult to till. The snow drift treatment was included because of the geometric nature of the snow drift accumulation. It had been observed that in most years snow drifts accumulated in an area beginning approximately $9 \mathrm{~m}$ from the fence and extending to about $30 \mathrm{~m}$. This area was designated as drift area.

Species performance was based on foliar cover at the end of the first growing season, and aboveground biomass production at the end of the second growing season.

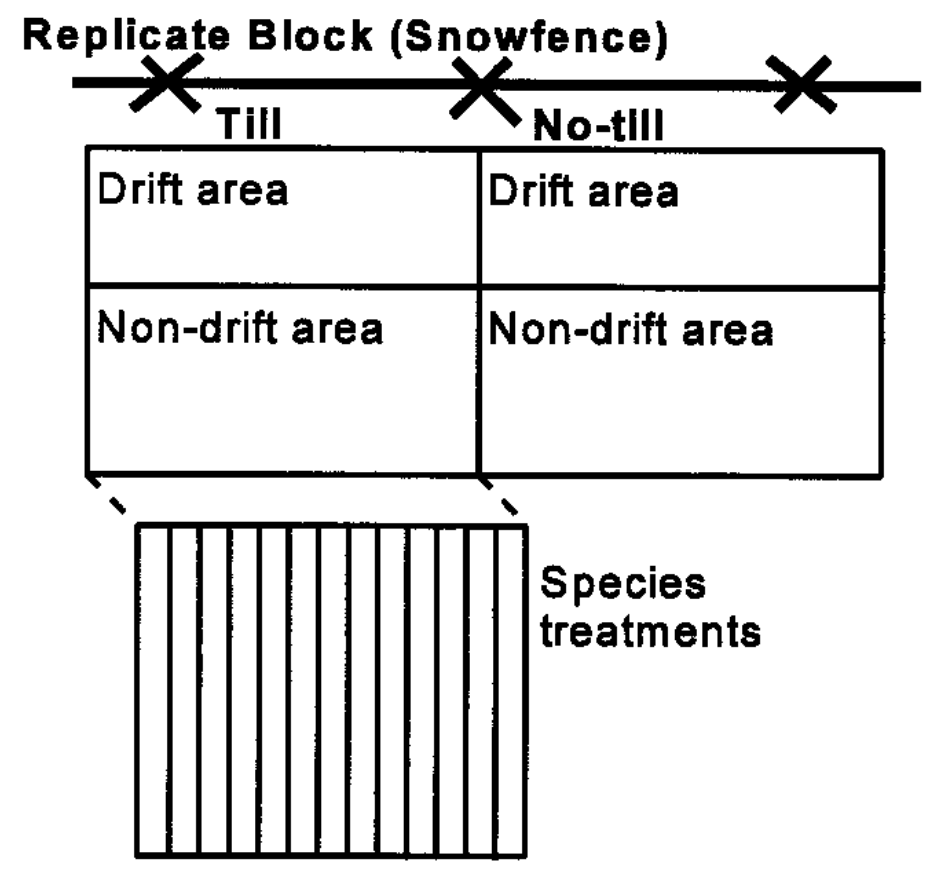

Fig. 1. Field plot diagram of a single replicate block. 
Snowfences and plots were located and marked in July 1990. Both till and no-till plots were sprayed in mid-July with an herbicide mixture of glyphosate [N-(phosphonomethyl) glycine] and chlorosulfuron [2-chloro- $N$-[[(4-methoxy-6-methyl-1,3,5triazin-2-yl)amino]carbonyl]benzenesulfonamide] at a rate of $2.3 \mathrm{~kg} / \mathrm{ha}$ and 0.07 $\mathrm{kg} / \mathrm{ha}$ active ingredient respectively, to reduce competition from antecedent native vegetation. Tilling operations were initiated in early September. Plots designated as till plots were tilled twice with a PTO-driven, rotary tiller.

Seeding operations were conducted in October of 1990. A Tye no-till drill with double disc openers and $20 \mathrm{~cm}$ row spacing was utilized. Each seeded plot was 2.0 $\mathrm{m}$ wide and $91 \mathrm{~m}$ in length aligned perpendicular to, and on the leeward side of the snowfence. The individual species assessed in the study were selected by a consensus of plant materials specialists and other natural resource professionals. The list included both native and introduced species, with a range of adaptations from very drought tolerant to more mesic species. Suspected variations in snowdrift extent suggested that some years are drought years, necessitating the testing of some drought tolerant species.

Species evaluated in the study were: mountain brome 'Bromar' (Bromus mar ginatus Nees.); altai wildrye 'Prairieland' (Leymus angustus Trin.); basin wildrye 'Magnar' (Leymus cinereus [Scribn. \& Merr.] A. Love); Russian wildrye 'Bozoisky' (Psathyrostachys junceus [Fisch.] Nevski); tall fescue 'Fawn' (Festuca arundinacea Schreb.); pubescent wheatgrass 'Luna' (Elytrigia intermedia [Host] Nevski); western wheatgrass 'Rosana' (Pascopyrum smithii [Rydb.] A. Love); thickspike wheatgrass 'Critana' (Elymus lanceolatus [Scribn. \& J.G. Smith] Gould); crested wheatgrass 'Ephraim' (Agropyron cristatum [L.] Gaertn.); slender wheatgrass 'Pryor' and 'San Luis' (Elymus trachycaulus [Link] ex Shinners); big bluegrass 'Sherman' (Poa ampla Merr.); and tufted hairgrass (Deschampsia caespitosa [L.] Beauv.). All species tested were considered nutritious and relatively palatable to wildlife and livestock. All species were seeded at the rate of 280 pure live seeds (PLS) $\mathrm{m}^{-2}$.

Foliar cover was measured with a 10 point frame at the end of the first growing season (Heady and Rader 1958). Aboveground biomass was estimated at the end of the second growing season utilizing a Neal Electronics Model 18-2000 capacitance meter (Neal and Neal 1966) and expressed as $\mathrm{kg} \mathrm{ha}^{-1}$. Measurements for both attributes were taken at prescribed intervals based on distance from the snowfence $(10 \mathrm{~m}, 12 \mathrm{~m}, 15 \mathrm{~m}, 18 \mathrm{~m}, 21$ m, $24 \mathrm{~m}, 27 \mathrm{~m}, 30 \mathrm{~m}, 36 \mathrm{~m}, 43 \mathrm{~m}, 49 \mathrm{~m}$, $55 \mathrm{~m}, 61 \mathrm{~m}, 67 \mathrm{~m}, 73 \mathrm{~m}, 79 \mathrm{~m}$, and $85 \mathrm{~m})$. Four, ten-point frames were located at each interval to measure foliar cover. Four capacitance meter readings were taken at each interval, and one capacitance meter sized quadrat was clipped at each interval. The clipped quadrat was located by slipping the quadrat over the capacitance meter so that the area clipped was the actual area read by the meter. A regression was performed with meter readings as the independent variable and biomass production the dependent variable. Biomass production was estimated for each unclipped meter reading based on the regression. Study areas were fenced to exclude livestock during the entire study period.

Analysis of variance (f-test) was performed with the SAS General Linear Model (SAS Institute 1985). All statistical comparisons were evaluated at $\mathrm{P} \leq 0.05$.

\section{Results and Discussion}

\section{Shallow Soil Site}

The analysis of foliar cover revealed benefits generally associated with tillage and enhanced moisture supply (Table 1). Till plot cover was approximately 3 times that of no-till plots $(4.2 \%$ and $1.2 \%$ respectively). Also as expected, drift area produced more cover than non-drift area (3.1\% and $2.3 \%$ respectively). The 3 -way interaction was not significant, however both drift $\mathrm{x}$ tillage and tillage $\mathrm{x}$ species interactions occurred, reflecting a difference in magnitude and not response.

Table 1. Shallow and deep soil site comparisons of foliar cover (\%) and aboveground biomass production $\left(\mathrm{kg} \mathrm{ha}^{-1}\right)$ for all species combined as effected by tillage and drift treatments.

\begin{tabular}{llc}
\hline \hline Treatment & & \\
\hline & $\%$ & $\mathrm{~kg} \mathrm{ha}^{-1}$ \\
(Shallow soil site) & & \\
till & $4.2 \mathrm{a}$ & $574 \mathrm{a}$ \\
no-till & $1.2 \mathrm{~b}$ & $88 \mathrm{~b}$ \\
drift & $3.1 \mathrm{a}$ & $376 \mathrm{a}$ \\
non-drift & $2.3 \mathrm{~b}$ & $335 \mathrm{a}$ \\
(Deep soil site) & & \\
till & $8.9 \mathrm{a}$ & $1,243 \mathrm{a}$ \\
no-till & $5.5 \mathrm{~b}$ & $548 \mathrm{~b}$ \\
drift & $5.0 \mathrm{a}$ & $517 \mathrm{a}$ \\
non-drift & $9.5 \mathrm{~b}$ & $1,266 \mathrm{~b}$ \\
\hline Values within a column with the same letter are not dif- \\
ferent, $\mathrm{P}<0.05$.
\end{tabular}

Till plot aboveground biomass production was significantly greater than no-till (Table 1). Till plots produced $574 \mathrm{~kg} \mathrm{ha}^{-1}$ versus $88 \mathrm{~kg} \mathrm{ha}^{-1}$ in no-till plots. There was no difference in biomass production between drift and non-drift treatments (Table 1); however, there was a tillage $\mathrm{x}$ drift interaction. The non-drift area-till plot combination produced approximately $20 \%$ more aboveground biomass than the drift area-till combination. This result was unexpected. These results emphasize the better response provided by tillage, but also reveal how the shorter growing season in the drift area may have suppressed tillage response and the additional moisture supply of drift melt water.

Pubescent wheatgrass (Luna), thickspike wheatgrass, and slender wheatgrass (Pryor) produced the most cover and aboveground biomass (Tables 2 and 3 ). The poor results of the San Luis slender wheatgrass variety was unexpected given the excellent results of the Pryor variety and positive tetrazolium tests.

\section{Deep Soil Site}

Tillage improved foliar cover of planted grasses on this site as well (Table 1). The difference between till and no-till, however, was less than that exhibited on the shallow soil site. This response was probably due to the higher degree of soil development and associated higher soil moisture reducing the magnitude of the tillage treatment effect. There was a difference between drift and non-drift area. Non-drift areas produced about twice as much foliar cover (Table 1), and no interactions were present.

The till treatment produced more biomass $\left(1,243 \mathrm{~kg} \mathrm{ha}^{-1}\right.$ vs. no-till $548 \mathrm{~kg} \mathrm{ha}^{-1}$, Table 1), and higher means for all species than no-till plots (Table 3 ). The non-drift portion of the plots outperformed the drift areas $\left(1,266 \mathrm{~kg} \mathrm{ha}^{-1}\right.$ and $517 \mathrm{~kg} \mathrm{ha}^{-1}$ respectively, Table 1).

As in the Shallow Soil Site study, there was a drift $\mathrm{x}$ tillage biomass production interaction. The drift area-till treatment combination performance was less than anticipated and the non-drift-till treatment combination performance was better than anticipated. We expected that the greater amount of available moisture in the drift area would correlate with higher biomass production. In both studies the mechanism responsible for this response may be the shortened growing season created by the presence of the snowdrift. Another possible contributing mechanism may be related to the precipitation equivalent. Unreplicated soil tests were conducted for background information and results indi- 
Table 2. Species percent cover as affected by tillage and drift treatments, across tillage and drift treatments.

\begin{tabular}{|c|c|c|c|c|c|c|c|c|c|c|}
\hline \multirow[b]{2}{*}{ shallow soil site } & \multicolumn{2}{|c|}{ till } & \multicolumn{2}{|c|}{ no-till } & \multicolumn{2}{|c|}{ drift } & \multicolumn{2}{|c|}{ non-drift } & \multicolumn{2}{|c|}{ overall } \\
\hline & $(\%)$ & $(\mathrm{SE})$ & $(\%)$ & (SE) & $(\%)$ & $(\mathrm{SE})$ & $(\%)$ & $(\mathrm{SE})$ & $(\%)$ & $(\mathrm{SE})$ \\
\hline slender wheatgrass (San Luis) & 1.4 & 0.4 & 0.4 & 0.1 & 0.6 & 0.2 & 1.2 & 1.0 & 0.9 & 0.8 \\
\hline slender wheatgrass (Pryor) & 7.8 & 0.4 & 2.4 & 0.6 & 6.7 & 4.4 & 3.5 & 2.7 & 6.4 & 5.1 \\
\hline pubescent wheatgrass (Luna) & 8.1 & 2.8 & 2.9 & 0.3 & 6.6 & 2.9 & 4.4 & 4.3 & 5.5 & 3.7 \\
\hline Russian wildrye (Bozoisky) & 5.8 & 2.5 & 1.2 & 0.5 & 2.8 & 1.4 & 4.1 & 4.2 & 3.5 & 3.1 \\
\hline western wheatgrass (Rosana) & 4.0 & 1.0 & 0.9 & 0.4 & 2.8 & 2.1 & 2.1 & 1.7 & 2.5 & 1.9 \\
\hline big bluegrass (Sherman) & 1.4 & 0.5 & 0.4 & 0.2 & 1.0 & 0.8 & 0.8 & 0.7 & 0.9 & 0.7 \\
\hline altai wildrye & 3.3 & 1.9 & 0.8 & 0.3 & 2.5 & 1.9 & 1.6 & 1.9 & 2.1 & 1.9 \\
\hline tall fescue (Fawn) & 3.1 & 1.1 & 1.3 & 0.3 & 2.9 & 1.3 & 1.4 & 1.1 & 2.2 & 1.4 \\
\hline tufted hairgrass & 0.4 & 0.1 & 0.2 & 0.1 & 0.4 & 0.4 & 0.2 & 0.2 & 0.3 & 0.3 \\
\hline mountain brome (Bromar) & 3.4 & 0.7 & 1.3 & 0.3 & 2.7 & 0.9 & 2.0 & 1.8 & 2.4 & 1.4 \\
\hline pubescent wheatgrass (Luna) & 16.6 & 1.6 & 6.0 & 3.7 & 10.0 & 8.7 & 12.6 & 17.0 & 11.3 & 13.3 \\
\hline Russian wildrye (Bozoisky) & 9.0 & 7.3 & 8.9 & 5.0 & 1.5 & 1.1 & 16.3 & 10.0 & 9.0 & 10.5 \\
\hline western wheatgrass (Rosana) & 9.1 & 4.8 & 6.0 & 3.4 & 3.5 & 1.5 & 11.6 & 8.7 & 7.6 & 7.3 \\
\hline crested wheatgrass (Ephraim) & 7.1 & 3.6 & 6.0 & 5.2 & 5.7 & 3.9 & 7.3 & 5.4 & 6.6 & 4.6 \\
\hline basin wildrye (Magnar) & 6.1 & 1.6 & 3.6 & 2.4 & 3.2 & 3.8 & 6.5 & 4.6 & 4.9 & 4.4 \\
\hline big bluegrass (Sherman) & 5.6 & 2.5 & 3.5 & 3.1 & 3.8 & 2.9 & 5.4 & 4.2 & 4.6 & 3.5 \\
\hline altai wildrye & 3.6 & 0.8 & 2.3 & 1.4 & 2.5 & 1.6 & 3.3 & 1.3 & 3.0 & 1.4 \\
\hline tall fescue (Fawn) & 1.4 & 1.5 & 1.3 & 1.3 & 2.3 & 2.1 & 0.5 & 0.7 & 1.4 & 1.8 \\
\hline tufted hairgrass & 1.0 & 1.0 & 0.2 & 0.4 & 1.0 & 1.0 & 1.0 & 0.7 & 0.9 & 0.8 \\
\hline mountain brome (Bromar) & 1.1 & 1.4 & 0.1 & 0.0 & 0.2 & 0.2 & 0.9 & 2.2 & 0.6 & 1.5 \\
\hline
\end{tabular}

Table 3. Species aboveground biomass production as affected by tillage and drift treatments, across tillage and drift treatments.

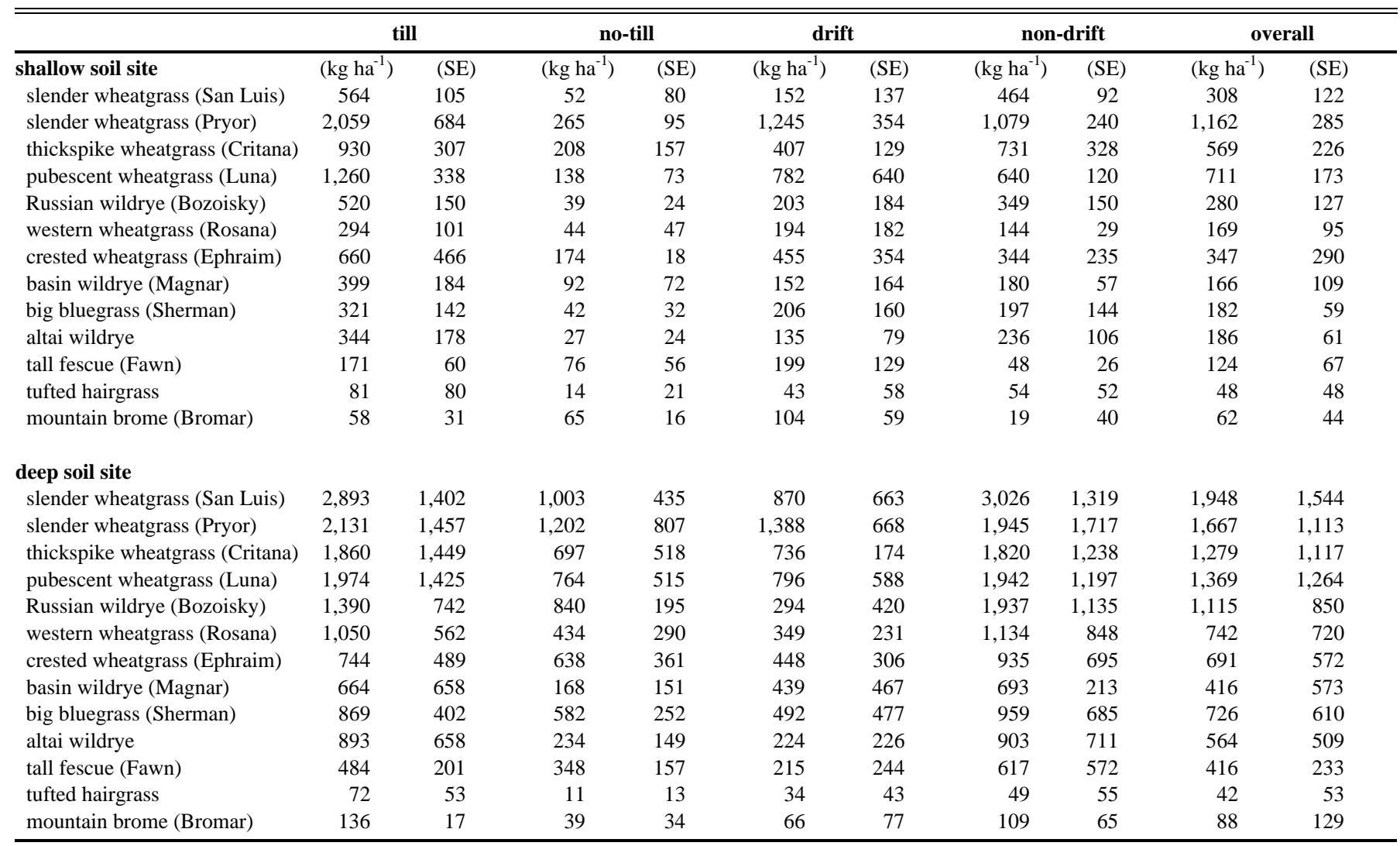


cated available phosphorus and nitrogen are unusually low or deficient in drift areas. One possible mechanism for this condition could be the leaching process occurring in the drift area each year. Drift areas are receiving, as precipitation equivalent, 2 to 3 times more moisture than the mean annual precipitation. Annual infiltration of $800-1,000 \mathrm{~mm}$ of additional water through the soil profile over the last 20 years, is sufficient to cause higher than normal leach rates. A more thorough soil analysis would be necessary to elucidate this phenomenon.

The San Luis variety of slender wheatgrass was the best performer in both cover and biomass production attributes. The alternate seedlot utilized for the Deep Soil Site provided a substantial performance improvement over performance of the Shallow Soil Site seedlot. All seedlots used in the project were less than 2 years old and manufacturer germination rates were verified by a second tetrazolium test. For unknown reasons the San Luis slender wheatgrass seedlot used in the Shallow Soil Site study did not germinate. We believe that, given the use of a quality seed lot, San Luis performance would have been excellent in both instances. Pubescent wheatgrass (Luna), slender wheatgrass (Pryor), and thickspike wheatgrass (Critana) were also superior in cover and aboveground biomass production. Overall, the results demonstrated the competitive and vigorous nature of wheatgrasses.

\section{Mitigation Implications}

Based on the results of this study, seed bed preparation by tillage was superior to the no-till preparation. This is true for all species tested in both studies. A few species including both slender wheatgrass varieties, and pubescent and thickspike wheatgrasses show some usefulness for no-till situations. Any attempt to reclaim mid-elevation snowfence sites or other areas of high snow accumulations (e.g., ski area mitigations in the Rocky Mountain west), should include species such as pubescent and thickspike wheatgrasses, and one or both varieties of the slender wheatgrasses included in this study. These species could be used successfully on both shallow and deep soil sites, and in drift and non-drift areas. (Non-drift areas are defined as areas without large, growing season limiting drifts). Pubescent wheatgrass (introduced) and thickspike wheatgrass (native) are long lived, rhizomatous and capable of forming a sod, and have the capability to quickly stabilize a site. This characteristic is important for erosion prone areas such as sloping sites and/or sites subjected to strong winds.

Slender wheatgrass varieties included in the study are also capable of quickly stabilizing a site. This native bunchgrass species also offers the option of increasing the morphological diversity of a seeded stand. However, this species is short-lived (Hafenrichter et al. 1968), and may not persist in stands after 5-10 years. Under good moisture conditions this species is an excellent seed producer, and this natural re-seeding ability may offset the shortlived nature (Hafenrichter et al. 1968). Shallow, drier sites may also require the inclusion of more drought tolerant species in a seed mixture along with the previously mentioned species. The introduced species, Russian wildrye and crested wheatgrass, may have some value in the event of dry year sequences. More mesic species such as basin wildrye and tall fescue may have some utility in mixes for reclaiming deeper, meadow sites.

In conclusion, it must be stated that these results are based on two years of observations. Sampling must be conducted in future years in order to determine the long term success of these reclamation efforts. The effect of tillage treatments may be less conspicuous after five or ten growing seasons. Future plant performance may also be strongly influenced by changing soil characteristics. A study of soil parameters as well as a fertilizer response study, may also need to be incorporated into any future assessment of cultural practices and species performance.

\section{Literature Cited}

Guernsey, P.J. 1996. Plant community and forage utilization changes at snowfences in southcentral Wyoming. M.S. Thesis 100p. University of Wyoming, Laramie, Wyo.

Hafenrichter, A.L., J.L. Schwendiman, H.L. Harris, R.L. MacLauchlan, and H.W. Miller. 1968. Grasses and legumes for soil conservation in the Pacific Northwest and Great Basin states. USDA Agr. Handb. 399, 69p. Washington, D.C.

Heady, H.F. and L. Radar. 1958. Modifications of the point frame. J. Range Manage. 11:96-98.

Martner, B.E. 1986. Wyoming Climate Atlas. Wyoming Water Research Center Pub. Univ. of Wyoming. 432p. Univ. of Nebraska Press, Lincoln, Neb.

Neal, D.L. and J.L. Neal. 1966. A new electronic meter for measuring herbage yield. U.S.D.A. Forest Service Note. PSW-56, 4p.
Pomeroy, A.L. 1990. A preliminary evaluation of the 1989 vegetation surveys of Wyoming Highway Dept. snowfences in southeastern Wyoming. Albany County Weed and Pest Dist. Rpt. 1 May 1990. 18p.

Pope, W.R. 1985. Soil changes associated with snow fences. M.S. Thesis $88 \mathrm{p}$. University of Wyoming, Laramie, Wyo.

SAS Institute. 1985. Statistics, Version 5. Cary N.C. SAS Institute $956 \mathrm{p}$.

Tabler, R.D. 1973. New snowfence design controls drifts, improves visibility, and reduces road ice. Proc: Annual Transp. Eng. Conf. 46:16-27.

Tabler, R.D. 1974. New engineering criteria for snowfence systems. Transportation Research Record 506. p. 65-78, Washington, D.C.

Tabler, R.D. 1985. Ablation rates of snowfence drifts at 2300 meter elevation in Wyoming. Proc: Western Snow Conf. 53:1-12.

Tabler, R.D. and R.P. Furnish. 1982. Benefits and costs of snow fences on Wyoming Interstate 80 . Transportation Research Record 860. p.13-20. National Academy of Sciences, Washington, D.C.

Weaver, T. and D. Collins. 1977. Possible effects of weather modification (increased snowpack) on Festuca idahoensis meadows. J. Range Manage. 30:451-456. 